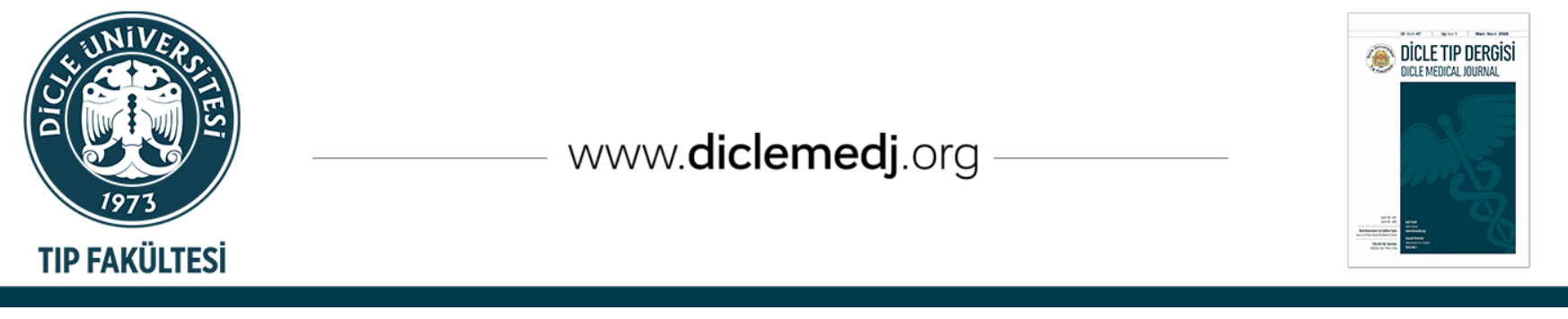

Editöre Mektup / Letter To Editor

\title{
Koronavirüs Cerrahi Vakalarında Genel Anestezi Yönetimi: Farklı Bir Fikir
}

\author{
Hakan Akelma ${ }^{1} 1$, Sedat Kaya iD 1 \\ 1 SBÜ Gazi Yaşargil Eğitim ve Araştırma Hastanesi, Diyarbakır Anesteziyoloji ve Reanimasyon Kliniği, Diyarbakır, Türkiye \\ Geliş: 01.04.2020; Revizyon: 02.04.2020; Kabul Tarihi: 08.04.2020
}

Öz

Aralık 2019'da, Çin'in Hubei Eyaleti, Wuhan'da yeni ve endişe verici şekilde bulaşıcı, şiddetli solunum yetmezliğine neden olan koronavirüs kısa zamanda dünyanın her tarafına yayılarak bugün yaklaşık 750 bin insanı enfekte etmiştir. Artan vaka sayısı sonucunda cerrahiye alınacak corona virüs hastasının sayısında da artma olmuștur. Biz bu yazımızda ameliyat geçirecek olan Covit-19 vakalarının preoperatif ve postoperatif dönemde enfeksiyonu yaymasını engelleyecek yeni fikirleri literatüre sunmayı amaçladık.

Anahtar kelimeler: Corona virüs, genel anestezi, cerrahi

DOI: 10.5798/dicletip.755785

Correspondence / Yazıșma Adresi: Hakan Akelma, Diyarbakır Gazi Yaşargil Eğitim ve Araştırma Hastanesi Anesteziyoloji ve Reanimasyon Kliniği e-mail: hakanakelma@hotmail.com 


\title{
General Anesthesia Management in Coronavirus Surgery Cases: A Different Idea
}

\begin{abstract}
In December 2019, the new and alarmingly infectious, severe respiratory failure causing corona virus in Wuhan, China's Hubei Province soon spread all over the world, infecting about 750 thousand people today. As a result of the increasing number of cases, there has been an increase in the number of corona virus patients to undergo surgery. In this Letter to the editor, we aimed to present new ideas to the literature that will prevent Covit-19 cases from spreading the infection in the preoperative and postoperative period.
\end{abstract}

Keywords: Corona virus, general anesthesia, surgical.

\section{Sayın Editör;}

İlk olarak 1960’lı yıllarda görülmeye başlayan Aralık 2019'da, Çin'in Hubei Eyaleti, Wuhan'da yeni ve endişe verici şekilde bulaşıcı, şiddetli solunum yetmezliğine neden olan koronavirüs 2 (SARS-CoV-2) enfeksiyonu salgını ortaya çıktığında tüm dünyanın dikkatini çekti. Önceki Corona virüs enfeksiyon nedeni olan SARS ve MERS koronavirüsüne benzeyen zoonotik bir Corona virüstü. 12 Şubat 2020'de DSÖ, yeni Corona virüsün neden olduğu hastalığı resmen Corona virüs Hastalığı 2019 (COVID-19) olarak adlandırd ${ }^{1}$.

8 Şubat 2020 itibariyle Çin'de 33 bin 738 teyit edilmiş vaka ve 811 ölüm bildirilmiștir, daha sonra tüm dünyaya yayılan virüs DSÖ tarafindan 13 Mart 2020 tarihinde pandemi olarak kabul edildi. Hastaların \%81 nin hafif asemptomatik geçirdiği, \%14 ünün klinik bulgu gösterdiği ve \%5 inin yoğun bakım gerektirdiği bilinmektedir $^{2}$. Şu an 29 Mart 2020 itibari ile 715 bin 521 teyitli vaka ve 33 bin 655 ölüm bildirilmiştir ${ }^{3}$. Vaka sayısı her geçen saatte de artmaktadır. Bu virüsun ${ }^{4}$ kuluçka dönemi 2-14 gün arasındadır. Asemptomatik ya da semptomatik hastaların belli anlarda cerrahi işlemlere maruz kalmaları, artan vaka sayısından dolayı kaçınılmazdır. Dolayısıyla ameliyathane sağlık çalışanlarının gerek preoperatif gerekse postoperatif dönemde kendilerini korumaları önem kazanacaktır. İște bu sebeple preopertif ve postoperartif dönemde sağlık profesyonellerinin corona virüsten nasıl korunacakları ile ilgili yeni inovatif yöntemlerden bahsetmek önem kazanacaktır. Gerek ameliyathane yönetimi gerekse de entübasyondan ekstübasyona kadar ameliyathanede oluşan tüm süreçte ameliyathanenin steril kalması, sağlık çalışanlarının enfekte olamamasını sağlamak yapılacak yeni inovatif çalışmalar ile en minimuma inecektir. Bizler son dönemde oluşan bu problemleri çözmek amaçlı farklı bir fikir ile yeni bir genel anestezi yönetimi yapmayı planladık. Konunun aciliyetine binaen hızlıca el çizimi yaparak literatüre katkıda bulunmak istedik. Bu çalışmanın bundan sonra yapılacak yeni çalışmalara ışık tutacağını düşünmekteyiz.

Çalışmamızın bazı limitleri mevcuttur. Birincisi konun aciliyetine binaen hızl el çizimleri ile yapılması, ikincisi bu yeni fikrin şuan ki yönetimde faydalı olacağı ancak yapılacak daha iyi çalışmalara ihtiyaç duymasıdır. İleride çoklu vakalar ile yapılacak çalışmaların bu yeni yöntemimize katkı sağlayacağını ayrıca çalışmamızın da literatüre ciddi katkı sağlayacağını düşüyoruz.

Yaptığımız bu çalışmada hastanın ameliyathaneye girişinden kliniğe transferine kadar geçen 5 aşamadan söz edeceğiz.

\section{AŞAMA}

\section{AMELIYYAT ÖNCESİ ALINACAK ÖNLEMLER}

Corona virüs pandemisi sırasında sağlık çalışanlarının kendilerini koruma ile ilgili yeterli sayıda genelge ve yönetmelikler vardır. Ve yönetmeliklere göre kişi kendini korumakla 
yükümlüdür. Bu planlama ile gerek acil gerekse elektif hasta ameliyathaneye giriş yaptıktan sonra preoperatif odasında kurulacak gerekli malzeme ve aletler ile ameliyathane dişından tam steril alana girmeden önce hastanın entübe edilmesi amaçlanmıştır. Hastanın preoperatif kapalı odada şartlara uygun olarak entübe edilmesi özellikle negatif basınçlı cerrahi odaya sahip olmayan ameliyathanelerde çalışanlarının korunmasını sağlayacaktır (Şekil 1).

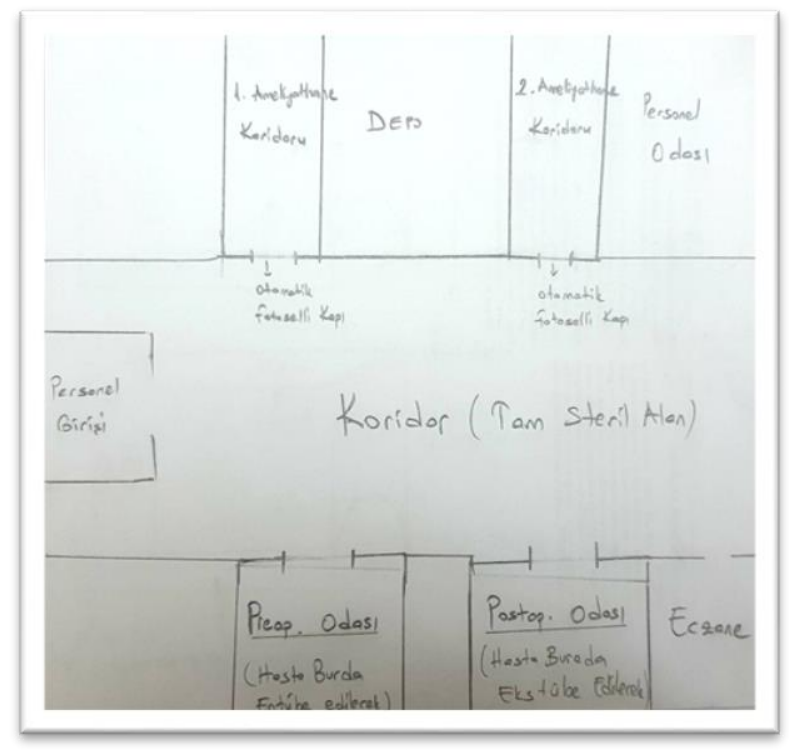

Şekil 1: Ameliyathane entübasyon ve ekstübasyon alanlarının hastaneye göre belirlenmesi için örnek çizim

\section{AŞAMA}

\section{ENTÜBASYON}

Hasta sedyeye alınır. Aeresol Box hastanın üzerine yerleştirilir. Arka kısmında boş kalan yerler steril örtüler ile hava kaçağı önlemek için kapatılır. Entübasyon sırasında (silinmesi) hasta tam kürarize edilip hızlı bir şekilde tek kullanımlık videolaringoskopi ile sağlanacaktır. Özellikle Aeresol Box içindeki hasta ekshalasyon havasının ortama yayımımı engellemek için, Aeresol Box'a bağlanmış bir aspiratör ucunun merkezi sistem aspirasyon öncesine bir HME (Bakteri-Virüs Filtresi) Filtre takılarak engellenir. Tasarladığımız Aeresol Box 'n en temel özelliği el girilen bölgenin el çıkarıldıktan sonra ortama hava verilmesini engelleyen bir valf sistemi olması, ayrıca Box'ın arkasındaki bölmenin hastayı iyi kavrayacağı şekilde raylı bir sisteme sahip olup havayı dışarı çlkarmada minimize etmesidir. Bu ek olarak bağlı aspiratör sistemi ile hava tahliyesi kolaylıkla yapılmakta, enfekte hava HME filtreden temizlenerek sisteme dâhil edilmektedir. Entübasyon tüpü bir klep ile kapatılıp, hastanın ekshale havası ve sekresyonlarından korunacak bir şekilde entübe edilir (Şekil 2,3,4).

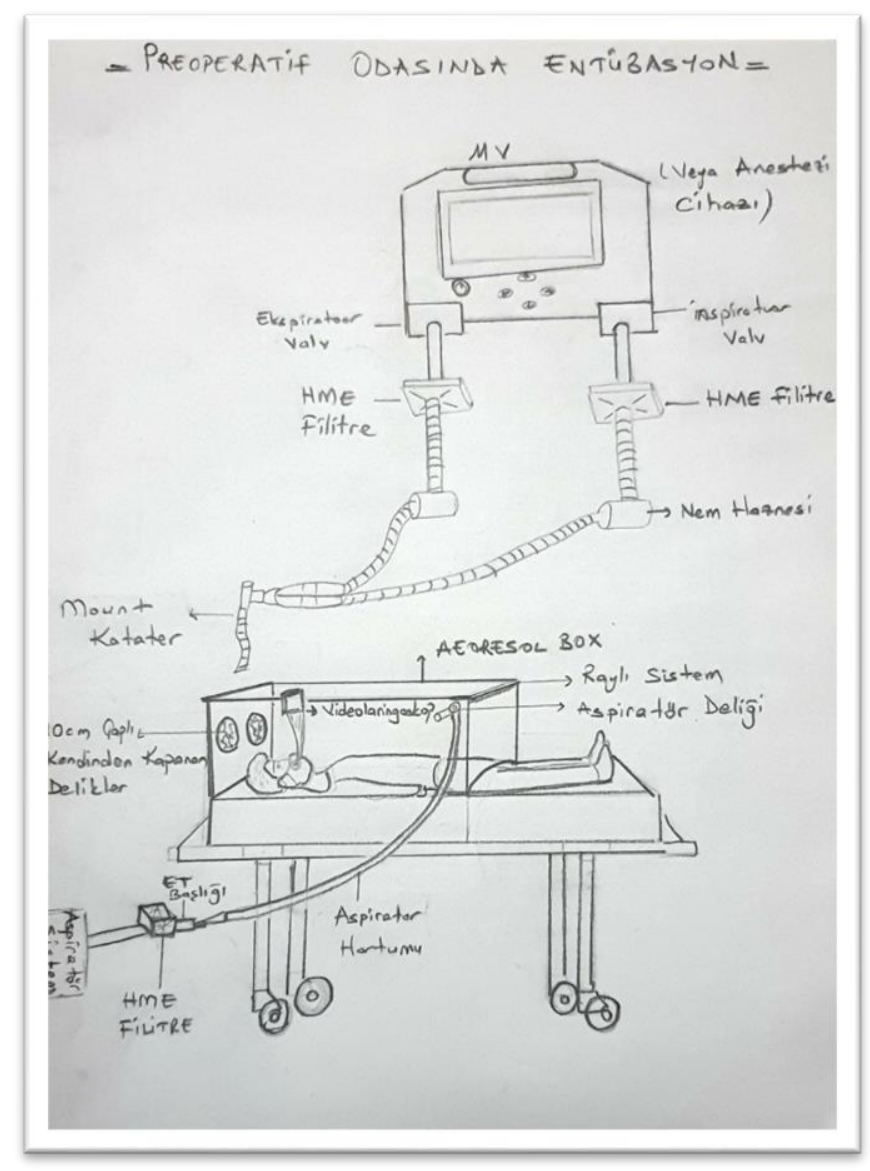

Şekil 2: Aeresol box, Aspiratör sistemi, Mekanik vantilatör bağlantısını gösteren görsel 


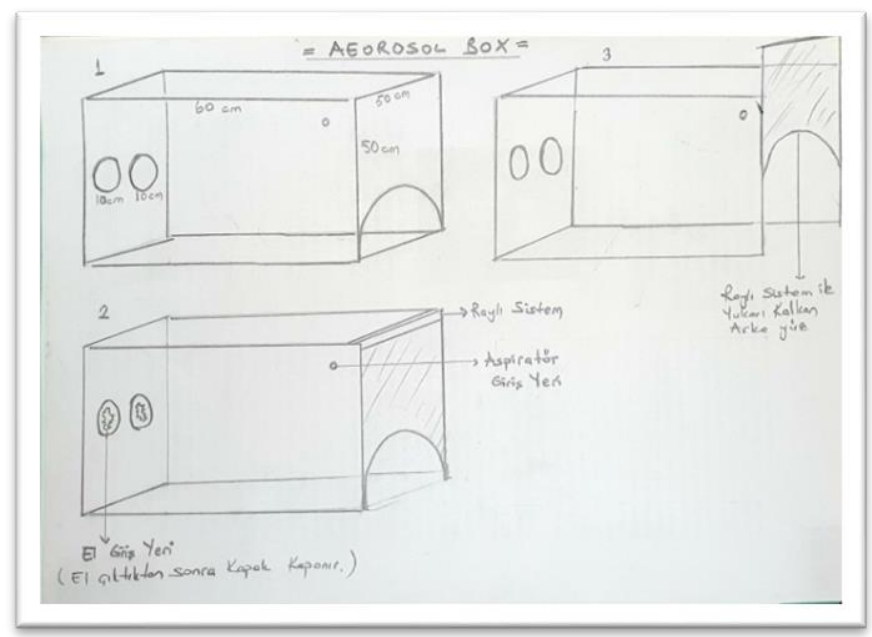

Şekil 3: Aeresol box dizaynı

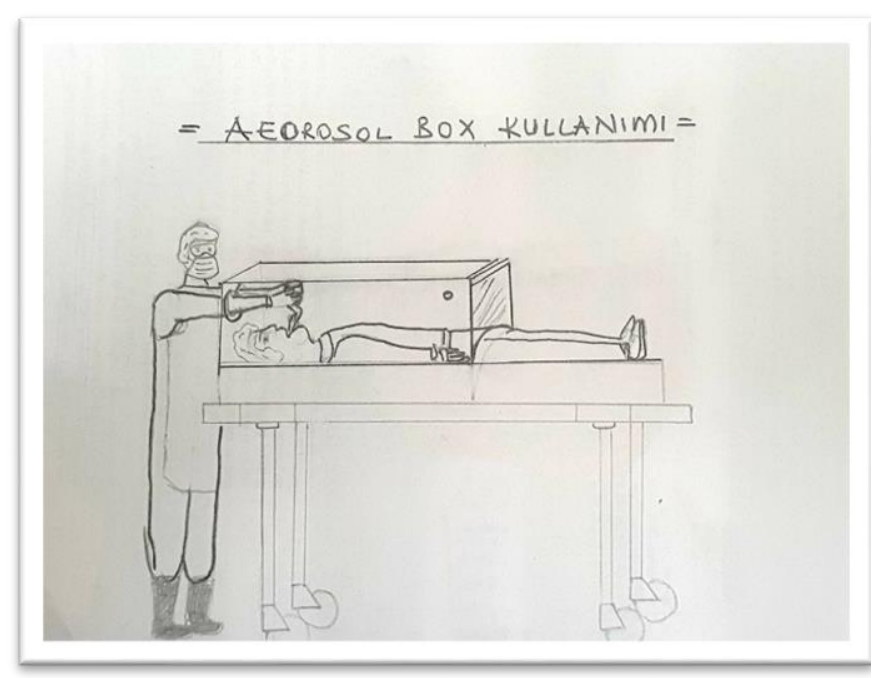

Şekil 4: Aeresol box ile entübasyon

\section{AŞAMA}

\section{KAPALI DEVRE AMBU SISTEMİ İÇíN MALZEMELER VE HAZIRLANIŞI}

Kapalı Devre Ambu Sitemi için sağlam saydam orta veya büyük boy bir poșet, tek kullanımlık ambu, entübasyon tüpü başlığı, yapıştırıcı bant ve havalandırma deliği için bir ucu sivri uzun iğne gerekir. Önce poşet ambunun başına proksimal 1/3 u kadar olan alana kadar giydirilir. Daha sonra hiç hava almayacak kadar yapışkan bant ile yapıștırılır. Sonrasında ambunun entübasyon tüpü ile olan bağlantı kısmına entübasyon tüpü yerleştirilir. İyice sıkıştırılır. Entübasyon tüpüne hava akıșı sağlaması için tüp başlı̆̆ının ambu ile bağlantılı deliğinden ucu sivri bir iğne ile hava yolu açılır. Böylece hasta havalandırılırken arkadaki rezervuar oksijen bölgesinden hastaya inspirasyon yapılırken, oksijenden zengin hava gider. Geriye gelen ekshalasyon havası ambunun üst kısmindaki ekshalasyon valvinden poşetin içine dolar ve hastadan gelen virüs içerikli hava poşette birikir (Şekil 5,6,7,8).

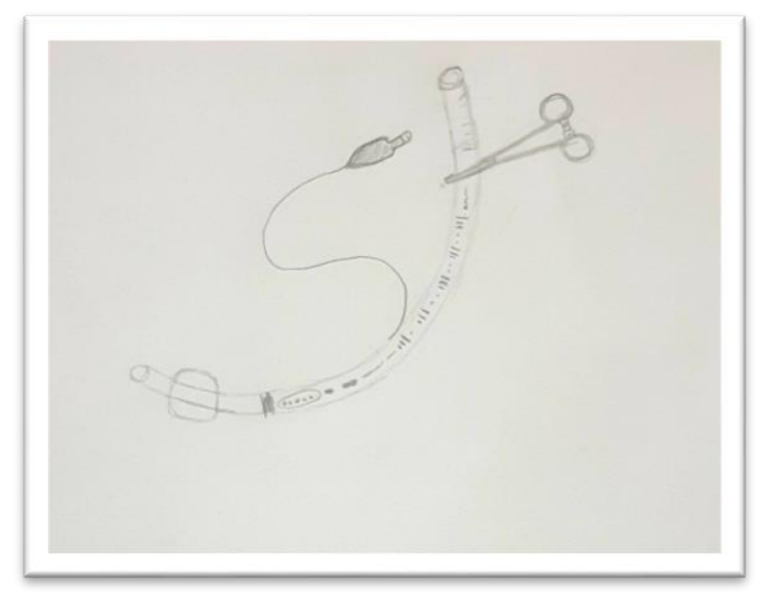

Şekil 5: Klempli başlıksız entübasyon tüpü

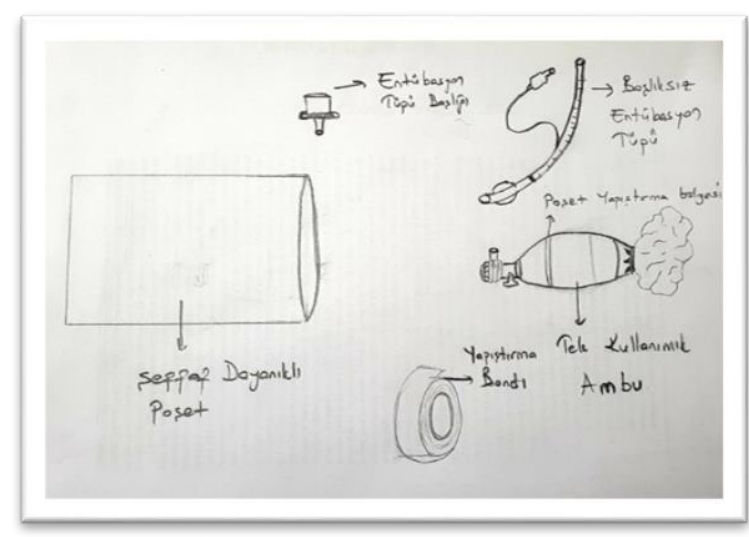

Şekil 6: Kapalı Devre Ambu Sistemi için gerekli malzemeler 


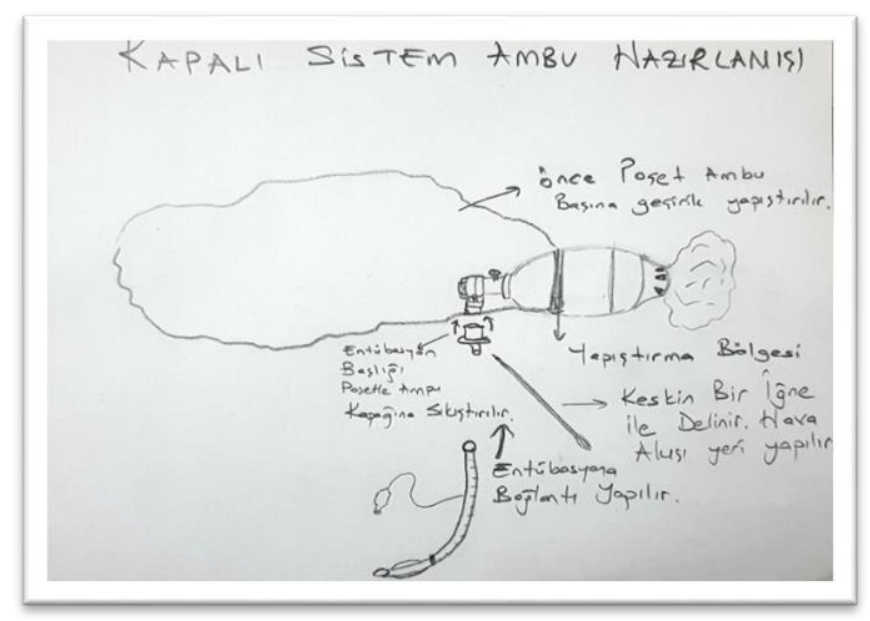

Şekil 7: Kapalı Devre Ambu Sistem hazırlanışı

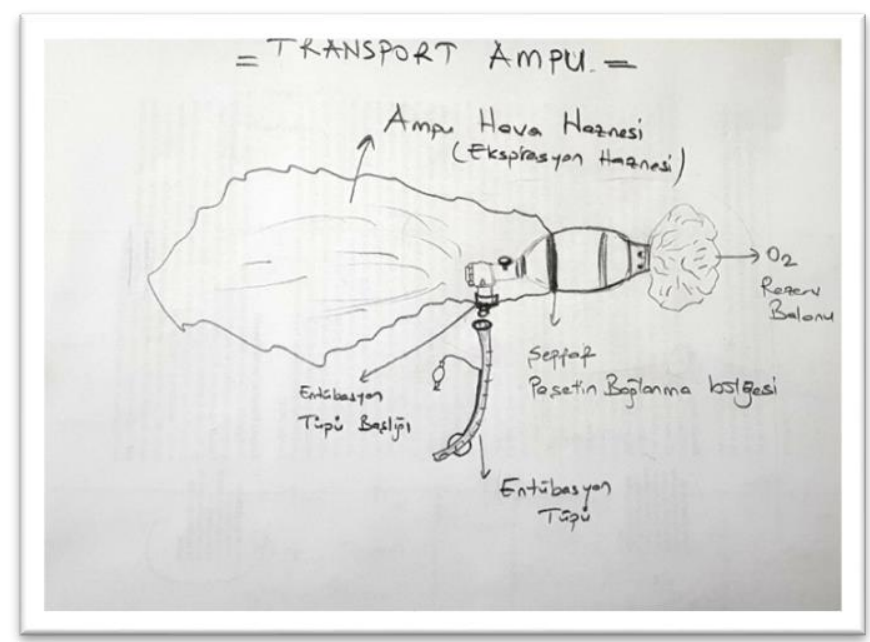

Şekil 8: Hazırlanmış Kapalı Devre Ambu Sistemi

\section{AŞAMA}

\section{TRANSFER}

Hasta ameliyathane Covit Cerrahi odasına kapalı devre ambu sistemi ve oksijen tüpü ile transfer edilir. Önerdiğimiz bu sistem sadece hastane içinde kısa mesafeli transferler için uygundur. Aynı transfer işlemi hastanın postoperatif yoğun bakım ünitesine transferinde de kullanılacaktır. Ameliyathane transferinden sonra anestezi cihazına bağlanan hastada kullanılan kapalı sistem ambu ve balon tıbbi atığa uygun şekilde bırakılacaktır (Şekil 9).

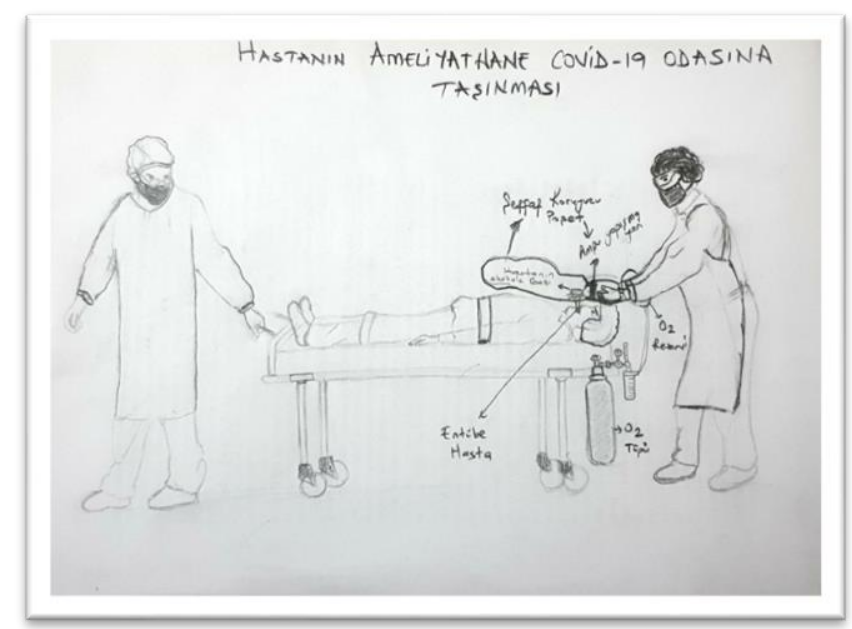

Şekil 9: Hastanın ameliyathane cerrahi odasına ve postoperatif odasina transferi modeli

\section{AŞAMA}

\section{EKSTÜBASYON, KULLANILAN MALZEMENIN ATILMASI VE KLİNİĞE TRANSFER}

Hasta postoperatif yoğun bakım ünitesine transfer edilir. Burada uyandırıldıktan sonra entübasyon tüpü hiç ambu bağlantı bölgesinde ayrılmadan hasta ekstübe edilir. Entübasyon tüpü hemen katlanarak ve bir yapıştırıcı bant etrafına sarılarak hava dışarı çıkması engellenir. Ekshalasyon için kullanılan poşette ambu etrafina sarılarak malzemeler steril bir şekilde imha edilmek üzere tıbbi atık çöpüne atılır (Şekil 10). Hasta kliniğe getirildiğinde tek kullanımlık oksijen sistemi ile güvenli bir şekilde transfer edilir. 


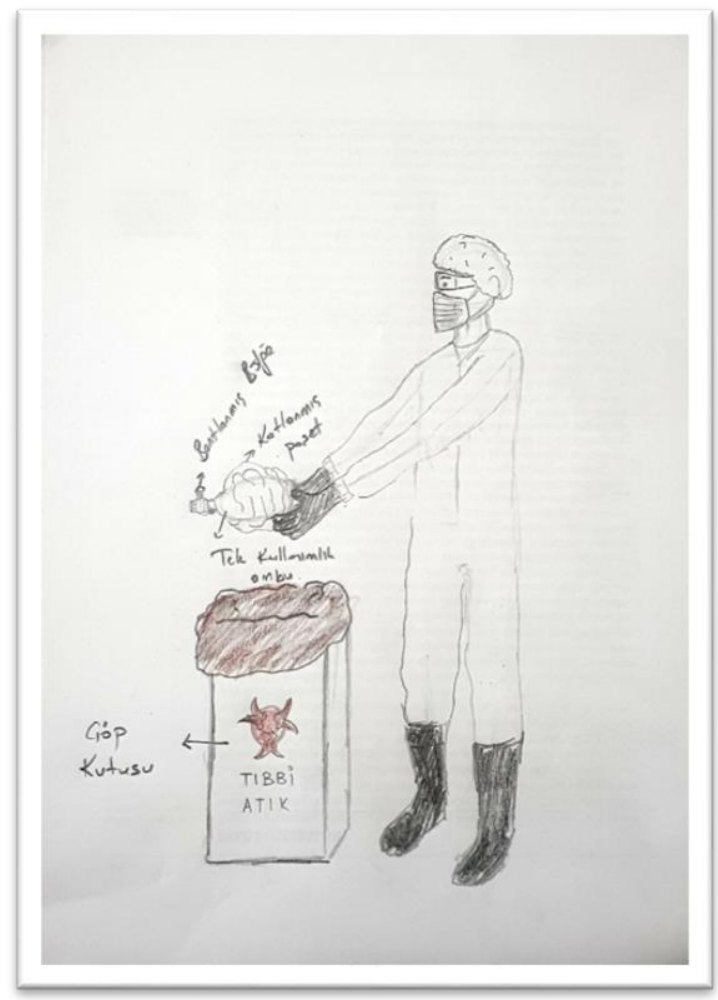

Şekil 10: Kapalı Devre Ambu Sisteminin tıbbi atık çöpüne atılması

Çıkar Çatışması Beyanı: Yazarlar çıkar çatışması olmadığını bildirmişlerdir.
Finansal Destek: Bu çalıșma herhangi bir fon tarafından desteklenmemiştir.

Declaration of Conflicting Interests: The authors declare that they have no conflict of interest.

Financial Disclosure: No financial support was received.

\section{REFERENCES}

1. https://www.who.int/emergencies/ diseases/n ovel-coronavirus-2019/events-asthey-happen.

2. Chen N, Zhou M, Dong $X$, et al. Epidemiological and clinical characteristics of 99 cases of 2019 novel coronavirus pneumonia in Wuhan, China: a descriptive study. The Lancet. 2020; 395: 507-13.

3. https://www.worldometers.info/coronavirus.

4. Yang HY, Xu J, Li Y, et al. The preliminary analysis on the characteristics of the cluster for the Corona Virus Disease. Zhonghua liuxingbingxue zazhi. 2020; 41: 623-28. 